\title{
ATOMIC ABSORPTION SPECTROMETRIC DETERMINATION OF TRACE ELEMENTS IN COAL BY USING AN ACID DIGESTION IN SEALED POLYTETRAFLUOROETHYLENE VESSEL
}

\author{
Ryozo NAKASHIMA, Eijiro KAMATA, and Shozo SHIBATA \\ Government Industrial Research Institute, Nagoya, Hirate-machi, \\ Kita-ku, Nagoya-shi, Aichi 462
}

As a wet digestion method of coal, digestion with nitricperchloric acid mixture was studied by using a sealed polytetrafluoroethylene(PTFE) digestion vessel. A PTFE inner vessel modified to this purpose was of $50 \mathrm{ml}$ capacity, put in an outer stainless steel vessel, and sealed tightly with a PTFE O-ring inserted between the vessel and a cover plate. Coal containing up to 86 $\%$ fixed carbon was sufficiently decomposed with the nitric-perchloric acid mixture $(1: 1)$ by heating at $150-160{ }^{\circ} \mathrm{C}$ for $7-14 \mathrm{~h}$. The sample preparation consisted of further digestion with hydrofluoric acid, followed by addition of boric acid, aqueous dilution and filtration. Nine elements in NBS 1632a coal were determined. Matrix elements of a calibration standard require no precise matching to the sample solution.

\section{INTRODUCTION}

It is important to know the quantities of toxic elements in coal for environmental pollution control from a coal-fired electric power plant and for disposal or utilization of fly ash. Instrumental neutron activation analysis 1$) 2$ (an not be utilized for a routine work because its process costs much. Since the ASTM analytical method for major elements ${ }^{3)}$ and eight trace elements 4 ) is based on ashing coal at $500{ }^{\circ} \mathrm{C}$, the method can not be used for the determination of volatile elements such as arsenic, boron and mercury.

Nadkarni ${ }^{5)}$ used inductively coupled plasma emission spectrometry for major, minor and trace elements in coal; preparation of the sample solution consisted of dry-ashing followed by digestion with a mixture of aqua-regia and hydrofluoric acid in a Parr bomb or by fusion with Claisse fluxer $\left(\mathrm{Li}_{2} \mathrm{~B}_{4} \mathrm{O}_{7}\right)$. To eliminate coal digestion step, a slurry injection atomic absorption spectrometry was studied by $0^{\prime}$ Reilly and coworkers 6$) 7$ ). A flameless atomic absorption spectrometry with a heated graphite atomizer was also reported and utilized for direct introduction of powdered coal samples ${ }^{8) 9)}$. However, a calibration problem still remains unsolved.

Flame atomic absorption spectrometry seems to be suited to the routine method of coal analysis. Although a few digestion method have been reported for 
volatile trace elements ${ }^{10) 11}$ ), the methods can not be fully used for multielements analysis. Hartstein ${ }^{12}$ reported an acid digestion method for coal samples using a Parr bomb, but the vessel was of insufficient capacity for digesting more than $0.5 \mathrm{~g}$ of coal and was likely to suffer leakage after repeated use. We have recently analyzed coal by flame atomic absorption spectrometry ${ }^{13)}$, in which the sample preparation involved nitric-hydrofluoric acid digestion followed by perchloricmetaperiodic acid digestion. A comparison of several sample digestion methods for cadmium analysis has been already reported ${ }^{14}$ ).

On the acid digestion of coal in sealed PTFE vessel, Nadkarni mentioned the disadvantage of either incomplete dissolution or losses of certain volatile elements. Furthermore, a contamination was noticed from the acids used and from an attack on metallic parts of the vessel by leaked acids. If an acid leakage from inner vessel could be eliminated, more vigorous dissolution condition may be applied without contamination from an outer vessel.

The present studies were undertaken to establish a simplified method of acid digestion by using a PTFE acid digestion vessel. The vessel was specially modified to secure against leakage. Coals of up to $86 \%$ fixed carbon(semianthracite) were found to be completely digested.

\section{EXPERIMENTAL}

\section{Apparatus}

A Hitachi 180-80 polarized Zeeman atomic absorption spectrometer was used. The layout of the PTFE acid digestion vessel used in this work was described previously 14). The inner vessel of $50 \mathrm{ml}$ capacity is made of PTFE and placed in an outer stainless steel vessel fitted with a screw cap. The inner vessel is sealed tightly with the aid of a PTFE 0-ring inserted between the vessel and the PTFE cover plate. The 0-ring(JIS B 2401, P 38) has a $37.7 \mathrm{~mm}$ inside diameter and a $3.5 \mathrm{~mm}$ thickness.

Standard solutions and chemicals

Standard solutions(1000 $\mathrm{mg} / \mathrm{l})$ of beryllium, cobalt, copper, chromium, manganese, nickel, lead, vanadium, and zinc were prepared by dissolving pure metals (99.99\%) in appropriate acid. The final concentration of free acid was adjusted to 0.2 M. Perchloric acid and nitric acid were of super special grade from Wako Pure Chemicals Co. Boric acid and hydrofluoric acid were of suprapur grade from E. Merck Chemicals Co.

Preparation of coal-digest solutions

One half gram of well pulverized coal, sieved through 60 mesh, is weighed in the PTFE vessel. Seven or more milliliters of nitric-perchloric acid mixture $(1: 1)$ is added. The 0-ring and the cover plate are put in place. The vessel is sealed by binding with teflon tape (Lab-Tape, 1 inch width and 0.08 mm thickness, manufactured by Chemplast Inc., N.J., USA) to prevent possible contamination from the outer container. The vessel is assembled and the stainless cap is screwed down tightly by hand. After heating at $150-160^{\circ} \mathrm{C}$ for $7-14 \mathrm{~h}$ according to quality of a sample coal, the vessel is cooled with tap water for 15 min. If leakage 
occurs on cooling, the cap is tightened further by hand. This is repeated whenever leakage occurs. The vessel is further cooled with ice water for $30 \mathrm{~min}$, and then opened. If cooling is insufficient, the digest may be lost by sudden foaming of the content. To the vessel $2.5 \mathrm{ml}$ of hydrofluoric acid is added. The vessel is again closed and heated at $120-130^{\circ} \mathrm{C}$ for $2 \mathrm{~h}$. To the digest $2.5 \mathrm{~g}$ of boric acid and a suitable amount of water are added. The vessel is covered and then warmed on a water bath to dissolve the acid. The content is cooled and diluted exactly to $50 \mathrm{ml}$. The solution is filtered immediately using a dried filter paper into a plastic bottle. The solution is analyzed with the condition for each element listed in Table 1 .

Table 1 Conditions for atomic absorption measurement

\begin{tabular}{|c|c|c|c|c|c|c|}
\hline Element & $\begin{array}{l}\text { Wavelength/ } \\
\text { nm }\end{array}$ & Flame & $\begin{array}{l}\text { Lamp } \\
\text { current/ } \\
\qquad \mathrm{mA}\end{array}$ & $\begin{array}{l}\text { Flow rate } \\
\text { of } \mathrm{C}_{2} \mathrm{H}_{2} / \\
(1 / \mathrm{min})\end{array}$ & $\begin{array}{l}\text { Burner } \\
\text { height/ } \\
\mathrm{mm}\end{array}$ & $\begin{array}{l}\text { Slit } \\
\text { width/ } \\
\text { nm }\end{array}$ \\
\hline $\mathrm{Be}$ & 234.9 & $\mathrm{~N}_{2} \mathrm{O}-\mathrm{C}_{2} \mathrm{H}_{2}$ & $12 \cdot 5$ & 6.8 & 8.7 & 1.3 \\
\hline Co & 240.7 & Air $-\mathrm{C}_{2}^{2} \mathrm{H}_{2}^{2}$ & 10.0 & 2.3 & $"$ & 0.4 \\
\hline $\mathrm{Cr}$ & 357.9 & $"$ & 7.5 & $3 \cdot 3$ & 11.2 & 1.3 \\
\hline $\mathrm{Cu}$ & 324.8 & $n$ & $"$ & 2.3 & 7.5 & 0.4 \\
\hline $\mathrm{Mn}$ & 279.5 & $n$ & $n$ & $n$ & 15 & $"$ \\
\hline $\mathrm{Ni}$ & 232.0 & $"$ & 10.0 & $"$ & 7.5 & 0.2 \\
\hline $\mathrm{Pb}$ & 283.3 & $"$ & 7.5 & $"$ & $"$ & 1.3 \\
\hline $\mathrm{V}$ & $318 \cdot 4$ & $\mathrm{~N}_{2} \mathrm{O}-\mathrm{C}_{2} \mathrm{H}_{2}$ & 12.0 & 5.6 & 10 & 0.4 \\
\hline $\mathrm{Zn}$ & 213.8 & $\mathrm{Air}-\mathrm{C}_{2} \mathrm{H}_{2}$ & 10.0 & 2.0 & 5 & 1.3 \\
\hline
\end{tabular}

Hollow cathode lamp: $\mathrm{Cr}$ Hamamatsu Photonics, others Hitachi.

Oxidant: $5.9 \mathrm{l} / \mathrm{min}$ for $\mathrm{Be}$ and $\mathrm{V}, 9.4 \mathrm{l} / \mathrm{min}$ for the others.

Preparation of synthetic coal-digest solutions

Standard solutions containing $5 \mathrm{mg} / \mathrm{ml}$ each of $\mathrm{CaO}, \mathrm{MgO}, \mathrm{K}_{2} \mathrm{O}$ and $\mathrm{Na}_{2} \mathrm{O}$ were prepared by using Spex standard materials, respectively. Standard solutions of similar concentration for $\mathrm{Al}_{2} \mathrm{O}_{3}$ and $\mathrm{Fe}_{2} \mathrm{O}_{3}$ were prepared by using Johnson Matthey standard $\mathrm{Al}$ and $\mathrm{Fe}$ metals, respectively. These materials were dissolved in a calculated amount of nitric acid and then diluted with water to $0.2 \mathrm{M}$ as free acid concentration. A standard solution of titanium(1mg/ml) for atomic absorption spectrometry obtained from Wako Pure Chemicals was used as a standard solution of $\mathrm{TiO}_{2}$. A standard solution of $\mathrm{SiO}_{2}(2.5 \mathrm{mg} / \mathrm{ml})$ was prepared by dissolving $2 \mathrm{~g}$ of $\mathrm{SiO}_{2}$ (Spex standard material) in $20 \mathrm{ml}$ of hydrofluoric acid and $10 \mathrm{ml}$ of nitric acid in the PTFE vessel. The solution was mixed with $20 \mathrm{~g}$ of boric acid and diluted to $800 \mathrm{ml}$ with water.

The synthetic coal-digest solutions were prepared on the basis that the ash content of coal was in the range of $3-25 \%$. A $0.5 \mathrm{~g}$ coal sample was taken and the digested solution was diluted to $50 \mathrm{ml}$. Furthermore, the representative composition of the eight major components in coal ashes was taken as $50 \% \mathrm{SiO}_{2}$, 25 
$\% \mathrm{Al}_{2} \mathrm{O}_{3}, 10 \% \mathrm{Fe}_{2} \mathrm{O}_{3}, 5 \%$ $\mathrm{CaO}, 5 \% \mathrm{MgO}, 2 \% \mathrm{~K}_{2} \mathrm{O}$, $2 \% \mathrm{Na}_{2} \mathrm{O}$ and $1 \% \mathrm{TiO}_{2}$ from analytical data elsewhere. The synthetic coal-digest solutions corresponding to $3 \%, 5 \%, 10 \%, 15 \%$, $20 \%$ and $25 \%$, ash-content coals were prepared by mixing the standard solution and by matching the acid concentrations to those in the sample preparation procedure. Some examples are listed in Table 2. In $10 \%$ ash-containing coal solutions, the content of $\mathrm{SiO}_{2}$ in the ash was altered to $30 \%$ and to $70 \%$, that

of $\mathrm{Al}_{2} \mathrm{O}_{3}$ to $15 \%$ and to $35 \%$, that of $\mathrm{Fe}_{2} \mathrm{O}_{3}$ to $5 \%$ and to $15 \%$, and that of $\mathrm{CaO}$ to $10 \%$ and to $15 \%$ respectively. In these cases, only one constituent was altered and the ratio of the rest components was left unchanged. In this manner, eight synthetic solutions of coal were made for $10 \%$ ash-containing hypothetical coal. The test solutions were similarly prepared for 5 and $20 \%$ ash-containing coals, and the acid concentrations were all matched to the standard procedure. Thus the thirty synthetic coal solutions were used to examine interferences of matrix constituents on the absorption signal of each trace element.

\section{RESULTS AND DISCUSSION}

Coal digestion

Samples of various quality of coal were digested by the procedure mentioned above with varying quantities and ratios of nitric and perchloric acid. Initially, the inside of the vessel must be dry to prevent dilution of the acid mixture. The digested solutions were decanted, and the residue was washed with water several times to remove hydrofluoric acid and then filtered with a millipore filter$(0.25 \mu \mathrm{m}$ of pore size). The specification of samples, the digestion conditions and the amount of residue are listed in Table 3.

The coals $(0.5 \mathrm{~g})$, Sheng Li, Huang Xien and Miike, were completely digested with the mixture of $5 \mathrm{ml}$ of nitric acid and $1.5 \mathrm{ml}$ of perchloric acid by heating at $150^{\circ} \mathrm{C}$ for $6-7 \mathrm{~h}$, but the digestion of coal of higher fixed carbon was not complete under the same conditions. When the mixture of $3.5 \mathrm{ml}$ of nitric acid and $3.5 \mathrm{ml}$ of perchloric acid was used, the digestion of coals containing $57-75 \%$ fixed carbon were still incomplete. However, the amount of residue was less than $1 \%$ of the sample taken in all cases. To digest anthracite, which was ranked semianthracite in the classification of ASTM coal rank, the digestion was remark- 
ably accelerated by applying elevated temperature $\left(160^{\circ} \mathrm{C}\right)$ and a prolonged heating time $(e . g \cdot 14 \mathrm{~h})$.

By using "Methods for Proximate Analysis of Coal and Coke"15), the fixed carbon and ash content in NBS 1632 a coal were found to be $43 \%$ and $22 \%$, respectively. The NBS coal was expected to be easily digested (like coals such as Sheng Li, Huang Xien and Miike of a comparative fixed carbon content), but the digestion was not so easy. The acid digestibility of coal may closely be related not only to fixed carbon content but also to ash content.

When increased amount of sample is required, the amount of the acid mixture should be increased proportionally. The 0-ring must be renewed each time, but it can be reused at least once more by treating at $150^{\circ} \mathrm{C}$ for several hours. The PTFE vessel can be used at least 30 to 40 times without amending the fitting groove for the $0-r i n g$ and the cover plate.

Table 3 Acid digestion of various coalsa)

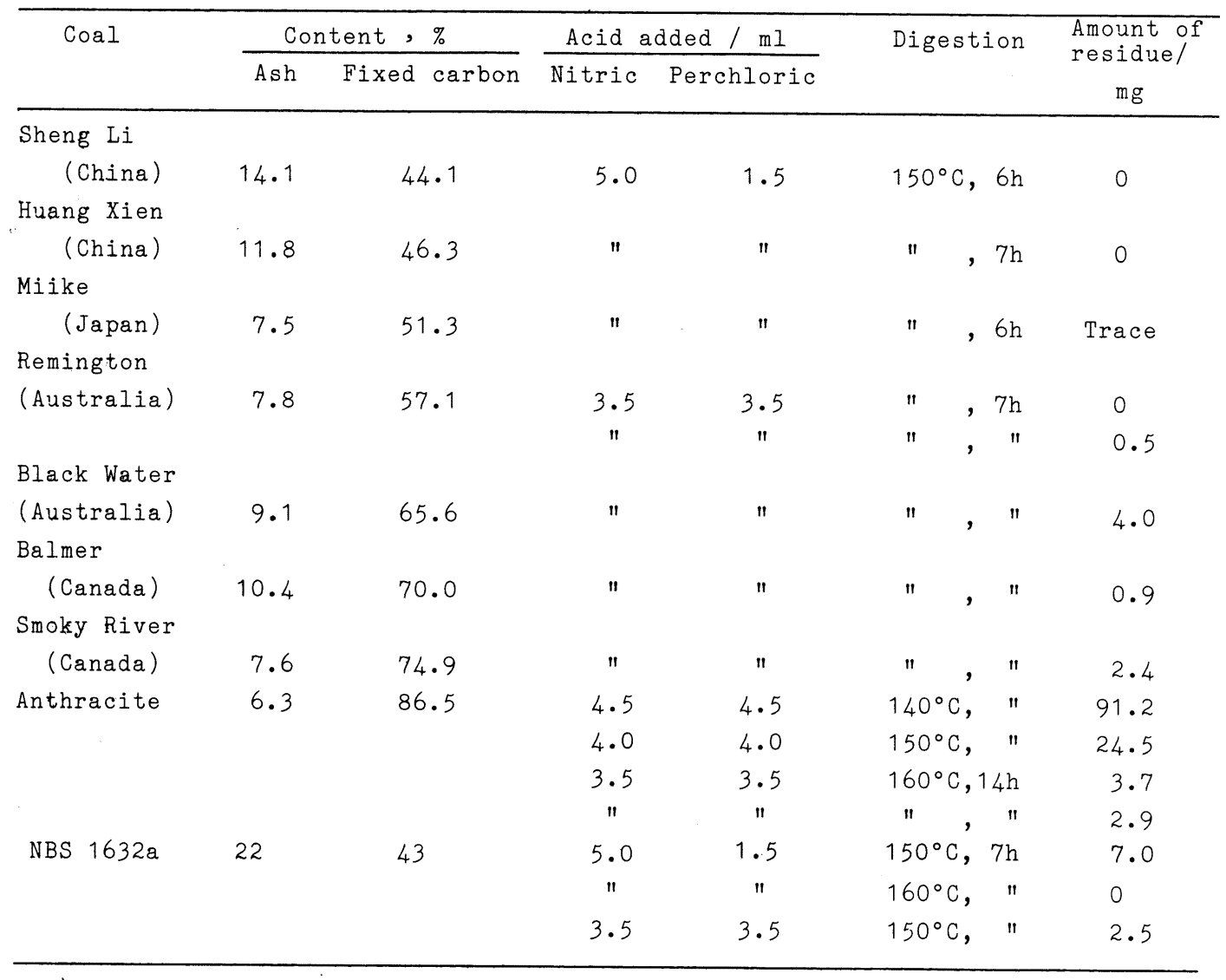

a) Coal taken, $0.5 \mathrm{~g}$.

Absorption signals in synthetic coal solutions

Five milliliters of synthetic coal solutions and a fixed volume below 50 $\mu l$ of a standard metal solution were taken into $10 \mathrm{ml}$ of plastic bottles and mixed 
well. In Table 4, the mean absorption signals and the relative standard deviation in the thirty solutions were listed with burner heights. The relative standard deviation were all within $2.7 \%$; thus the interference suppression of fluoroboric acid was effective for these nine elements. The relative standard deviation of manganese was smaller at a burner height of $15 \mathrm{~mm}$ than at $7.5 \mathrm{~mm}$; hence interference suppression was ineffective at the lower height. When the burner height was increased, the suppression became gradually effective and the absorption signals were increased. The burner height was similarly critical for the suppression of interference on chromium. The absorbance for chromium was highest at a burner height of $8.7-10 \mathrm{~mm}$ and was lowered at the height of $11.3 \mathrm{~mm}$ by $20 \%$ of the highest value. However, the relative standard deviation in the thirty solutions was lowest at $11.3 \mathrm{~mm}$.

Table 4 Interference suppressing effect of fluoroboric acid and sensitivity

\begin{tabular}{|c|c|c|c|c|c|c|}
\hline \multirow[t]{2}{*}{ Element } & \multirow{2}{*}{$\begin{array}{c}\text { Concentration, } \\
\text { ppm }\end{array}$} & \multirow{2}{*}{$\begin{array}{l}\text { Burner } \\
\text { height/ } \\
\mathrm{mm}\end{array}$} & \multicolumn{2}{|c|}{ Absorption signal } & \multicolumn{2}{|c|}{ Sensitivity ${ }^{a}$} \\
\hline & & & $\mathrm{mm}$ & R.S.D. \% & Slavin & $\begin{array}{r}\text { Present } \\
\text { method }\end{array}$ \\
\hline $\mathrm{Be}$ & 0.5 & 8.7 & $80.8 \pm 1.3$ & 1.6 & 0.03 & 0.04 \\
\hline Co & 1.0 & $"$ & $81.4 \pm 1.6$ & 2.0 & 0.10 & 0.07 \\
\hline $\mathrm{Cr}$ & 2.0 & 11.3 & $83.4 \pm 1.9$ & 2.3 & 0.15 & 0.14 \\
\hline $\mathrm{Cu}$ & 1.0 & 7.5 & $40.1 \pm 0.6$ & 1.5 & 0.1 & 0.15 \\
\hline \multirow[t]{2}{*}{$\mathrm{Mn}$} & $"$ & $n$ & $70.5 \pm 9.1$ & 12.9 & & \\
\hline & $"$ & 15 & $110.2 \pm 2.0$ & 1.8 & 0.08 & 0.05 \\
\hline $\mathrm{Ni}$ & $n$ & 7.5 & $86.3 \pm 0.8$ & 0.9 & 0.1 & 0.07 \\
\hline $\mathrm{Pb}$ & 2.0 & $"$ & $69.3 \pm 1.3$ & 1.9 & 0.5 & 0.3 \\
\hline V & 5.0 & 10 & $40.1 \pm 0.9$ & 2.2 & 1.3 & 0.7 \\
\hline $\mathrm{Zn}$ & 0.4 & 5 & $88.3 \pm 2.4$ & 2.7 & 0.04 & 0.03 \\
\hline
\end{tabular}

a) $\mathrm{g} / 1 \%$ absorption

The sensitivities expressed by the concentration of $1 \%$ absorbance were listed also in Table 4 with reference to Slavin's values ${ }^{16)}$. The values in the present work were comparable with those of Slavin. From the experimental data, these elements can be determined by the calibration curve method using only a synthetic coal solution(e.g. $10 \%$ ash-containing coal, cf. Table 2) without matrix matching.

Coal analysis

A half gram of NBS 1632 a coal was analysed, and the results were listed in Table 5. The sample was also analysed with the solution digested with $1.5 \mathrm{ml}$ of perchloric acid and $5 \mathrm{ml}$ of nitric acid at $150^{\circ} \mathrm{C}$ for $7 \mathrm{~h}$, and the results were also listed in the table. The absorption signals were all measured by integration for $5 \mathrm{~s}$ except those of beryllium, cobalt and vanadium which were measured for $10 \mathrm{~s}$. The analytical values in the partially digested solutions (e.g. the third column) showed somewhat larger R.S.D. than those average of the present method. This would be attributed to incomplete digestion. The recovery of chromium was 
persistently 20-30\% lower in the partially digested solutions than in the fully digested solutions. Large amount of chromium was detected in the residue after digestion, but the recovery of the other metals was good in spite of incomplete digestion.

Table 5 Analytical result of NBS SRM 1632a coal

\begin{tabular}{|c|c|c|c|c|c|c|c|c|c|}
\hline \multirow[t]{2}{*}{ Element } & \multirow{2}{*}{$\begin{array}{c}\text { NBS } \\
\text { certified, } \\
\text { ppm }\end{array}$} & \multicolumn{4}{|c|}{$\begin{array}{l}\text { Digest with } 5 \mathrm{ml} \mathrm{HNO}_{3} \text {, } \\
1.5 \mathrm{ml} \mathrm{HClO}\end{array}$} & \multicolumn{4}{|c|}{ Present method } \\
\hline & & & $\mathrm{ppm}$ & & R.S.D \% & & ppm & & R.S.D \% \\
\hline $\mathrm{Be}$ & & & & & & 1.53 & $3 \pm 0.04$ & $(6)^{b)}$ & 3 \\
\hline Co & $\left.(6.8)^{a}\right)$ & $7 \cdot 3$ & \pm 1.3 & $(12)^{b)}$ & 18 & 6.7 & \pm 0.9 & $(6)$ & 13 \\
\hline $\mathrm{Cr}$ & $34.4 \pm 1.5$ & 26.0 & \pm 2.0 & $(10)$ & - & 36.9 & \pm 1.0 & $(5)$ & 3 \\
\hline $\mathrm{Cu}$ & $16.5 \pm 1.0$ & $15 \cdot 7$ & \pm 1.6 & $(12)$ & 10 & $15 \cdot 3$ & \pm 0.9 & $(6)$ & 6 \\
\hline $\mathrm{Mn}$ & \pm 2 & 28.5 & \pm 2.3 & (8) & 8 & 28.6 & \pm 0.7 & $(4)$ & 2 \\
\hline $\mathrm{Ni}$ & $19.4 \pm 1.0$ & $19 \cdot 5$ & \pm 3.2 & (8) & 16 & 18.9 & \pm 1.2 & (6) & 6 \\
\hline $\mathrm{Pb}$ & $12.4 \pm 0.6$ & 13.9 & \pm 1.5 & $(8)$ & 10 & 12.0 & \pm 0.5 & $(6)$ & 4 \\
\hline $\mathrm{V}$ & \pm 3 & 44 & \pm 7 & (9) & 15 & 45.5 & \pm 1.6 & (6) & 4 \\
\hline $\mathrm{Zn}$ & \pm 2 & 27.6 & \pm 1.8 & $(12)$ & 7 & 27.6 & \pm 2.4 & (6) & 9 \\
\hline
\end{tabular}

a) The value is not certified. b) The figures in the parenthesized columns are the numbers of determinations.

Table 6 Analysis of Smoky River coal and Black Water coal

\begin{tabular}{|c|c|c|c|c|}
\hline \multirow[b]{2}{*}{ Elements } & \multicolumn{2}{|c|}{ Smoky River coal } & \multicolumn{2}{|c|}{ Black Water coal } \\
\hline & $\begin{array}{l}\text { Present } \\
\text { method, } \\
\text { ppm }\end{array}$ & $\begin{array}{l}\mathrm{HClO}_{4}-\mathrm{HIO}_{4} \\
\text { method, } \\
\text { ppm }\end{array}$ & $\begin{array}{l}\text { Present } \\
\text { method, } \\
\text { ppm }\end{array}$ & $\begin{array}{l}\mathrm{HClO}_{4}-\mathrm{HIO}_{4} \\
\text { method, } \\
\text { ppm }\end{array}$ \\
\hline $\mathrm{Cr}$ & 8 & 8 & 9 & 7 \\
\hline $\mathrm{Cu}$ & 10 & 8 & 13 & 10 \\
\hline $\mathrm{Mn}$ & 5 & 6 & 114 & 133 \\
\hline $\mathrm{Ni}$ & 7 & 6 & 37 & 38 \\
\hline $\mathrm{Pb}$ & 5 & 4 & 37 & 35 \\
\hline V & 20 & 25 & 20 & 20 \\
\hline $\mathrm{Zn}$ & 7 & 8 & 360 & 390 \\
\hline
\end{tabular}

Chromium was seemed to be oxidized to hexavalent state in the present method. On the other hand, in the partially digested solution, chromium may still remain in some lower-valence state which is strongly adsorbed on the residual material. Manganese was seemingly converted to manganese dioxide in the present method, and the recovery from the supernatant was 50-60\% low. When the digest was treated with $2 \mathrm{ml}$ of $30 \%$ hydrogen peroxide prior to the addition of hydrofluoric acid, the metal was completely recovered. Thus manganese was determined by 
the method using additional treatment with hydrogen peroxide.

To verify the applicability of the present method, coal samples of higher fixed carbon such as Smoky River and Black Water coals were analysed in comparison with those by $\mathrm{HClO}_{4}-\mathrm{HIO}_{4}$ digestion method ${ }^{13)}$. The results are shown in Table 6. The analytical values by the present method are shown as the mean of two determinations. The agreement of both methods were reasonably good.

We thank Dr. H. Kakiyama(Government Industrial Research Institute, Kyushu) for his courteously supplying various coal samples.

We thank Mr. K. Itomi and H. Tsunekawa(Aich Institute of Technology) for their assistance in this work.

\section{REFERENCES}

1) J. M. Ondov, W. H. Zoller, I. Olmez, N. K. Aras, G. E. Gordon, L. A. Rancitelli, K. H. Abel, R. H. Filby, K. R. Shah, R. C. Ragaini: Anal. Chem., 47, 1102 (1975).

2) M. S. Germani, I. Gokman, A. C. Sigleo, G. S. Olmez, A. M. Small, D. L. Anderson, M. P. Failey, M. C. Gulovali, C. E. Choquette, E. A. Lepel, G. E. Gordon, W. H. Zoller: Anal. Chem., 52, 240 (1980).

3) Standard Test Method for Major and Minor Elements in Coal and Coke Ash by Atomic Absorption, ASTM D3682 (1978).

4) Standard Test Method for Trace Elements in Coal and Coke Ash by Atomic Absorption, ASTM D3683 (1978).

5) R. A. Nadkarni: Anal. Chem., 52, 929 (1980).

6) J. E. O'Reilly, M. A. Hale: Anal. Lett., 10, 1095 (1977).

7) J. E. O'Reilly, D. G. Hicks: Anal. Chem., 51, 1905 (1979).

8) E. S. Gladney: At. Absorp. Newsl., 16, 42 (1977).

9) L. Ebdon, W. C. Pearce: Analyst(London), 107, 942 (1982).

10) T. C. Rains, 0. Menis: J. Assoc. Off. Anal. Chem., 55, 1339 (1972).

11) P. Aruscavage: J. Res. U.S. Geol. Survey, 5, 405 (1977).

12) A. M. Hartstein, R. W. Freedman, D. W. Platter: Anal. Chem., 45, 611 (1973).

13) E. Kamata, R. Nakashima, K. Goto, S. Shibata: Bunseki Kagaku, 31, 551 (1982).

14) R. Nakashima, E. Kamata, K. Goto, S. Shibata: Bunseki Kagaku, 32, T92 (1983).

15) JIS M-8812 (1976).

16) W. Slavin: "Atomic Absorption Spectroscopy", (1983), (Interscience Publishers, New York)

Keyword phrases

atomic absorption spectrometry; determination of metals in coal; beryllium, cobalt, chromium, copper, manganese, nikel, lead, vanadium, and zinc in coal; oxidative digestion of coal in polytetrafluoroethylene vessel. 